\title{
SERUM LACTATE DEHYDROGENASE ISOENZYMES AS MARKER FOR LUNG TISSUE DAMAGE IN ACUTE BRONCHITIS PATIENTS
}

\author{
Abdul Shakoor Memon, Habibullah Qureshi, Muhammad Ali Memon, \\ Badar-u-Din Memon and M. Saleh Memon
}

\begin{abstract}
BACKGROUND/OBJECTIVES: Total serum lactate dehydrogenase (LDH) and LDH isoenzymes are found increased in tissue damaging diseases. Literature reveals that LDH and its isoenzymes specifically LDH-3 increase in blood due to damage of lung tissue. Acute bronchitis is diagnosed only on clinical grounds and no laboratory tests had been established to confirm diagnosis. This study was conducted to establish a guiding factor that can be helpful in assessment of lung tissue damage and this finding will be having prognostic importance including drug effectiveness in acute bronchitis patients which can be helpful in prevention of developing the chronic course of illness.

METHODS: Patients were collected from Out Patients Department of Liaquat University Hospital Jamshoro I Hyderabad, Sindh - Pakistan. Total serum LDH was estimated by spectrophotometer and LDH isoenzymes were measured by electrophoresis on cellulose acetate membrane.

RESULTS: Total serum LDH $(260.84 \pm 7.08 \mathrm{mu} / \mathrm{ml} p<0.001)$ and LDH-3 $(65.60 \pm 1.92 \mathrm{mu} / \mathrm{ml} p<0.001)$ were found statistically significant as compared to control subjects.

CONCLUSION: Increased serum LDH and LDH-3 are marker for extent of lung tissue damage. Monitoring of these parameters can be a better guide for the prognosis and treatment including drug effectiveness in patients of acute bronchitis.
\end{abstract}

KEY WORDS: LDH isoenzymes. Acute bronchitis. Cellulose acetate electrophoresis.

\section{INTRODUCTION}

Acute bronchitis is one of the most common diseas$\mathrm{es}^{1,2}$ presented by cough ${ }^{3,4}$ and fever. ${ }^{5}$ It is acute tracheobronchial inflammation; caused by pyogenic organism and viruses ${ }^{4}$ predisposed by various factors like cold, damp, dusty, atmosphere air pollutants. ${ }^{6,7}$ The inflammatory reaction causes mucinous and inflammatory secretions and injure the tracheobronchial mucosa leading to lung tissue damage. Lactate Dehydrogenase (LDH) is found in all human tissues, its normal serum concentration is due to normal tissue breakdown, which significantly increases after tissue damage. ${ }^{6}$ There are five LDH isoenzymes present in blood, which are classified according to their electrophoretic mobility. LDH-1 moves faster while LDH-5 is the slowest one. Increased LDH isoenzymes levels indicate the organ specific origin of disease such as LDH-1, LDH-2 in heart, erythrocytes, kidneys and brain; LDH-3 in lungs, pancreas, adrenals, spleen, thymus, thyroid, lymph nodes and leukocytes; LDH-4 in skeletal muscles and the LDH-5 in liver.

\section{SUBJECTS AND METHODS}

Patients were collected from Out Patients Department of Liaquat University Hospital Hospital Jamshoro/ Hy- derabad, Sindh - Pakistan. Study included both male and female subjects between ages of 20-40 years after getting consent on a proper proforma. Twenty five patients and 20 matching healthy subjects were selected excluding other possible diseases supposed to interfere the results e.g., diabetes mellitus, tuberculosis, thyrotoxicosis etc. Samples were collected in plain bottles on $2^{\text {nd }}$ day of acute febrile condition of distressing cough, chest pain and fever. Serum was separated and applied for electrophoresis according to the method by Moses and Ross, ${ }^{9}$ using cellulose acetate as medium, barbital tris citrate buffer $\mathrm{pH} 8.5$, voltage $350 \mathrm{~V}$ for 30 minutes. Separated isoenzyme bands were stained by layering over an agar gel reaction mixture containing lactate substrate, buffer, NAD, nitro-blue-tetrazolium and phenazine methosulphate, followed by de-staining and then densitometry for quantitative results. Total serum LDH estimation was performed by 4010 spectrophotometer using the kits from Merck Company. All the experiments were carried out in the laboratory of Biochemistry Department University of Sindh, Jamshoro.

\section{RESULTS}

The findings of total LDH and different isoenzymes of LDH in acute bronchitis patients and controls are pre- 
sented in Table I. Results are expressed as mean \pm S.E.M and statistically analyzed for significance by two tailed $T$ test. The calculations were done with SPSS version 10.0 (Statistical Package for Social Sciences). Total LDH $(260.84 \pm 7.08 \mathrm{mu} / \mathrm{ml})$ and isoen- zymes LDH-3 $(65.60 \pm 1.92 \mathrm{mu} / \mathrm{ml})$ were significantly higher $(p=<0.001)$ as compared to control subjects. However, isoenzymes LDH-1, LDH-2, LDH-4, LDH-5 were not statistically significant as compared to controls.

TABLE I:

VALUES OF TOTAL SERUM LDH AND LDH ISOENZYMES IN ACUTE BRONCHITIS PATIENTS (The values are in mean \pm S.E.M )

\begin{tabular}{|c|c|c|c|c|c|c|}
\hline & Total LDH & \multicolumn{5}{|c|}{ LDH Isoenzymes } \\
\hline & & LDH-1 & LDH-2 & LDH-3 & LDH-4 & LDH-5 \\
\hline Control $(n=20)$ & $188.82 \pm 7.72$ & $86.3 \pm 2.70$ & $72.0 \pm 3.86$ & $28.60 \pm 2.16$ & $17.00 \pm 0.71$ & $20.00 \pm 0.55$ \\
\hline $\begin{array}{l}\text { Acute bronchitis patients } \\
(n=25)\end{array}$ & $260.84 \pm 7.08$ & $90.16 \pm 1.40$ & $65.92 \pm 3.36$ & $\stackrel{\bullet}{65.60 \pm 1.92}$ & $17.76 \pm 0.46$ & $17.96 \pm 0.84$ \\
\hline$p$-value & $<0.001$ & N.S & N.S & $<0.001$ & N.S & N.S \\
\hline
\end{tabular}

- Statistically significant as compared to controls. N.S = Non-significant.

\section{DISCUSSION}

In acute bronchitis, the predisposing factors and causative agents cause bronchial epithelial injury followed by lung tissue damage ${ }^{6,7,10}$ resulting in the release of LDH-3 into extracellular fluid followed by rise in serum levels, thus giving general rise of total $\mathrm{LDH}$ and remarkable rise in $\mathrm{LDH}-3$ values in serum. ${ }^{11-14}$ The diagnosis of acute bronchitis is purely clinical without standardized diagnostic signs and sensitive or specific confirmatory laboratory tests. ${ }^{6,15}$ Different studies $^{7,15,17-19}$ had been performed for diagnosis of this disease and identification of causative organisms but none was found successful to establish confirm diagnosis. In our study, significant rise of LDH-3 in serum of acute bronchitis patients was seen as compared to healthy normal controls indicating excessive lung tissue damage and release of isoenzymes in blood which is helpful in diagnosing acute bronchitis like the role of other isoenzymes in diagnosing different diseases e.g. cardiac or hepatic diseases. While significant rise of total $\mathrm{LDH}$ is due to relative rise in LDH-3. In confirmation to our study, high LDH and its isoenzymes were found in other similar studies on infants ${ }^{20}$ and childre ${ }^{21}$ suffering from acute bronchitis. This study also can be utilized in prognosis of acute bronchitis by monitoring effect of treatment which can be helpful in arresting the progress of disease otherwise going chronic course e.g. chronic bronchitis, COPD, etc. Drugten, et al in one of his study ${ }^{22}$ has also demonstrated the response of treatment on LDH levels in idiopathic pulmonary fibrosis.

\section{CONCLUSION}

It is concluded that in acute bronchitis; increased total serum LDH with remarkable rise in serum LDH-3 can be used as the marker for (1) diagnosis of disease indicating extent and the severity of lung tissue damage (2) prognosis, to assess treatment and drug effectiveness, (3) to save the patients from developing the chronic course of disease by guiding to control further damage to lung tissue and other resultant health hazards. Further, serum electrophoretic analysis of LDH and LDH isoenzymes is good diagnostic and prognostic tool, and the results can be obtained within short time and are cost-effective.

\section{REFERENCES}

1. Meza RA, Bridges-Webb C, Sayer GP, et al. The management of acute bronchitis in general practice: results of the Australian morbidity and treatment survey, 1990-1991. Aust Fam Physician. 1994; 23: 1550-53.

2. Dunlay J, Reinhardt R. Clinical features and treatment of acute bronchitis. J Fam Pract. 1984; 18 (5): 719-22.

3. Oeffingr DC, Snell LM, Foster BM, et al. Diagnosis of acute bronchitis in adults: a national survey of family physicians. J Fam Pract. 1997; 45: 402-9.

4. Braman SS. Chronic cough due to acute bronchitis. ACCP evidence-based clinical practice guidelines. Chest. 2007; 129: 95S-115S

5. Mufson MA. Viral pharyngitis, laryngitis, croup and bronchitis. In Goldman L, Bennett JC, eds, Cecil's Textbook of Medicine. $21^{\text {st }}$ Edition. Philadelphia: WB Saunders, 2000: Pp. 1793-4.

6. Hueston WJ, Mainous AG III. Acute bronchitis. Am Fam Physician. 1998; 57:1270-82.

7. Boldy DA, Skidmore SJ, Ayres JG. Acute bronchitis in the community; clinical features, infective factors, changes in pulmonary function and bronchial reactivity to histamine. Resp Med. 1990; 84: 
377-85.

8. Bernstein LH, Seinto P. Two methods compared for measuring LD-I/ total LD activity in serum. Clin Chem. 1986; 32: 792-96.

9. Moss GC, Ross ML, Henderson AR. Ten electrophoretic methods compared with a selected method for quantifying lactate dehydrogenase isoenzyme in serum. Clin Chem. 1988; 34: 188590.

10. Periman PE, Ginn Dr. Respiratory infections in ambulatory adults choosing the best treatment. Postgrad Med. 1990; 87: 175-84.

11. Drent M, Cobben NAM, Henderson RF, et al. BAL fluid LDH activity and LDH isoenzyme pattern lipoid pneumonia caused by an intravenous injection of lamp-oil. Eur Resp J. 1996; 9: 2416-18.

12. Drent M, Cobben NAM, Dieijen-Visser van MP, et al. Serum lactate dehydrogenase activity: indicator of the development of pneumonitis induced by amiodarone. Eur Heart J. 1998; 19: 969-70.

13. Matusiewiez SP, Williamson IJ, Sime PJ, et al. Plasma lactate dehydrogenase $L$ : a marker of disease activity in cryptogenic fibrosing alveolitis and extrinsic allergic alveolitis. Eur Resp J. 1993; 6: 1282-86.

14. DeRemee RA. Serum lactate dehydrogenase activity and diffuse interstitial pneumonitis. JAMA. 1968; 204: 103-5.

15. Gillissen A, Gessner C, Hammerschmidt S, et al.
Acute bronchitis: when are antibiotics, and when is symptomatic treatment indicated? MMW Fortschr Med. 2006; 148(1-2): 26-8.

16. Gwaitney JM Jr. Pulmonary bronchitis. In: Mandell $\mathrm{GL}$, Bonnet JE, Dolin R, eds. Principles and practice of infectious diseases. $4^{\text {th }}$ ed. New York: Churchil Livingstone, 1995: Pp. 606-8.

17. Williamson HA Jr. Pulmonary function test in acute bronchitis: evidence for reversible airway obstruction. J Fam Pract. 1987: 25(3): 251-6.

18. Flack G, Heyman L, Gnrpe J, et al. Chlamydia pneumoniae (TWAR): a common agent in acute bronchitis. Scand J Infect Dis. 1994; 26: 179-87.

19. Gonzales R, Bartlett JG, Besser RE, et al. Treatment of uncomplicated acute bronchitis: background. Ann Intern Med. 2001; 134: 521-9.

20. Baldini G, Capuccio A, Ruschi A, et al. Lactate dehydrogenase isoenzymes and alveolar inflammation in acute severe bronchiolitis in infants. Ed Med Chir. 1992; 14 (6): 597-600.

21. Gordeeva GF, Rzaeva RG. Clinical significance of changes in the activity of LDH and LDH isoenzymes in acute bronchitis in children. Pediatrics. 1988; (3): 110.

22. Drugten van M, Cobben NAM. Lamers RJS, et al. Serum LDH: a marker of disease activity and its response to therapy in idiopathic pulmonary fibrosis. Neth J Med. 1996; 48:229-33.

\begin{tabular}{l} 
AUTHOR AFFILIATION: \\
Dr. Abdul Shakoor Memon (Corresponding Author) \\
Assistant Professor \\
Department of Biochemistry \\
Liaquat University of Medical \& Health Sciences \\
Jamshoro, Sindh - Pakistan. \\
Prof. Habibullah Qureshi \\
Biochemistry Department \\
Muhammad Medical College, Mirpurkhas, Sindh - Pakistan. \\
Prof. Muhammad Ali Memon \\
Department Of Biochemistry \\
Isra University Hyderabad, Sindh - Pakistan. \\
Dr. Badar-u-Din Memon \\
Senior Medical Officer \\
NIMRA, Jamshoro \\
Prof. M. Saleh Memon \\
Department of Biochemistry \\
Muhammad Medical College, Miprurkhas, Sindh - Pakistan. \\
\hline
\end{tabular}

